\title{
Lipid Profile Changes in Toxoplasmosis Aborted Women
}

\author{
Azhar Hatif Al-Kuraishi* Huda Hamed Hasan** \\ Shatha M. J. Al-Kateeb** \\ Received 22,February,2012 \\ Accepted 28,May,2012
}

\begin{abstract}
:
Blood lipids are important mediators of host defense during the acute phase of innate immunity. Parasites may induce significant changes in lipid parameters, as has been shown in vitro study where substitution of serum by lipid/cholesterol in medium and in experimental models (in vivo). Thus changes in lipid profile occur in patients that having active infections with most of the parasites. Toxoplasma cannot synthesize cholesterol and depends upon acquisition of low density lipoprotein (LDL)-derived from the host cell, via endocytosis mediated by the LDL receptor or the LDL receptor-related protein. The present study is conducted to evaluate the changes in lipid profile in $T$. gondii infected women.A total of patients included 87 aborted women who had positive test for toxoplasmosis and a two control groups (115 non toxoplasmosis women): The first control group (negative control) contains 88 apparently healthy women and the second control group (positive control) contains 87 aborted women, were registered from Al-Yarmouk Teaching Hospital in Baghdad. Both control groups had negative test for toxoplasmosis. These samples were collected between the period January 2009 and May 2010. Patients and controls women's had comparable age that ranged between 15-45 years old. Serum samples were collected from each woman in the three groups and then the Enzyme Linked Immunosorbant Assay (ELISA) and Lipid profile assays were performed by using two commercial kits. In the basis of ELISA test anti-T. gondii antibodies (IgG and $\operatorname{IgM}$ ), detected in the patients sera, three types of toxoplasmosis were identified. These were; acute type, sub-acute type and chronic type. Most of patients had chronic type 75 (86.2\%). There were significant decreased in the total cholesterol are 165.05 (control groups 212.44, 213.33 respectively), triglycerides 134.98 (control groups 173.81, 174.40 respectively), LDL 87.78 (control groups 137.32, 135.87 respectively) and vLDL values 26.99 (control groups $34.70,34.60$ respectively). In contrast, there was significant increased in HDL value (49.0) as compared with control groups (40.42, 38.78 respectively). Also the result indicated that there were no significant differences in lipid profile values between the three types of disease.

Toxoplasma gondii had a role in changes lipid profile values in infected women which characterized by decrease in cholesterol and triglyceride and LDL with a significant increases in HDL level. Further studies needed to maintain the effect of duration of the toxoplasmosis (acute or chronic) on the changes in lipid profile.
\end{abstract}

Key words: Lipid profile, toxoplasmosis, aborted women.

\section{Introduction:}

Toxoplasmosis is an infectious disease of worldwide endemic distribution. It is caused by an obligatory intracellular protozoan parasite $T$. gondii. The parasite is able to infect all warm-blooded animals (including human beings) as intermediate hosts, who become infected either by ingested water and foodstuff contaminated (directly or indirectly) with cat feces containing mature oocyst or by ingesting raw or undercooked meat containing tissue cysts [1]. The course of infection by $T$. gondii is generally benign, as the vast majority of the infected human population remains asymptomatic or presents only mild symptoms. However, the infection can cause significant morbidity and mortality in the developing fetus and in 
immunocompromised individuals [2]. Infection contracted during the first trimester of pregnancy induces the most severe symptoms, while in the second and third trimesters, the severity of lesions decrease [3]. In Arab and regional countries, the prevalence of toxoplasmosis was ranged between $26-81.4 \%$ [4, 5, 6]. In Iraq toxoplasmosis studies have reported different prevalence rates, ranged between $19.1-25.2 \%$ [7, 8] Blood lipids are important mediators of host defense during the acute phase of innate immunity. Infection and inflammation typically decrease blood total cholesterol (total-C) and high density lipoprotein cholesterol

(HDL), but may increase triglycerides $[9,10]$. Recent observations suggested that cholesterol exerts many actions by maintaining a specialized type of membrane domain and have been thought to act as platform through which signal transduction events are coordinated and pathogens gain entry to infect host cells $[11,12]$. Relationship of serum cholesterol levels in man infected with parasites has drawn the attention of various workers. Since it has been shown in vitro studies that parasites like Giardia and Entamoeba can grow in lipid rich media in the absence of serum, it would be interesting to determinate the mechanism of lipid/cholesterol utilization. The requirement of cholesterol for internalization of eukaryotic pathogens; like Leishmania, Plasmodium and Toxoplasma under variable circumstances are poorly understood $[11,13]$. There is an emerging body of evidence showing that the intracellular protozoan $T$. gondii alters host cell metabolism for entry and replication and uses host metabolic products for its own metabolic pathways [14] because Toxoplasma cannot synthesize cholesterol and depends upon acquisition of low density lipoprotein (LDL)-derived from the host cell, via endocytosis mediated by the LDL receptor [15] or the LDL receptor-related protein [16]. So, the present study is conducted to evaluate the changes in lipid profile in $T$. gondii infected women.

\section{Materials and Methods:}

i. Subjects collection: Blood samples (without EDTA) were collected from 87 aborted women who had the curettage operations at the Obstetric and Gynecology Department of Al-Yarmouk Teaching Hospital in Baghdad. They had positive test for toxoplasmosis by ELISA test. These samples were collected between the period January 2009 and May 2010. Also two control groups were collected (total 115 women). The first one, 88 apparently healthy women referred to the laboratory unit of Al-Yarmouk Teaching Hospital for marriage testing profile and the second control group contains 87 aborted women. Both groups had negative test for toxoplasmosis (ELISA test). These samples were used as negative control and positive control group, respectively. The patient and control women's had comparable age that ranged between 15-45 years old. Five $\mathrm{ml}$ of venous blood were collected from each patient and control individual. The blood was placed in a plain tube and left to stand for 30 minutes at room temperature to clot. Then, the tube was centrifuged (2000 rpm) for 10 minutes to collect serum, which was frozen at $-20^{\circ} \mathrm{C}$ after dividing it into aliquots $(0.5 \mathrm{ml}$ in each).

ii. Enzyme Linked Immunosorbant Assay (ELISA): This assay was performed using two commercial kits (Biokit Diagnostics Company, Spain) for the detection of IgG and IgM anti-T. gondii antibodies in serum. This test was performed for each patients and controls.

iii. Lipid profile assays: Total cholesterol (C), Triglycerides (TGS) and High-Density Lipoprotein (HDL), were determined using a standard enzymatic assay (Linear chemicals, Montgat-Barcelona, Spain). Whereas, Low-Density Lipoprotein (LDL) and very Low-Density Lipoprotein (v LDL) were calculated by the Friedewald formula [17]:

$$
\begin{aligned}
\mathrm{LDL} \mathrm{mg} / \mathrm{dL} & =\mathrm{C}-\mathrm{HDL}-\mathrm{TGS} / 5 \\
\mathrm{v} \mathrm{LDL} \mathrm{mg} / \mathrm{dL} & =\mathrm{TGS} / 5
\end{aligned}
$$


iv. Statistical analysis: Data were presented for the qualitative data in terms of observed numbers and percentage, frequencies and significant differences $(\mathrm{P} \leq 0.05,0.01$ or 0.001 ) between the groups of the study were assessed using Pearson Chi-square test. For quantitative data they were presented in terms of mean, standard error of the mean, range and significant differences $(\mathrm{P} \leq 0.05,0.01$ or 0.001$)$ were assessed by analysis of variance (ANOVA test) for more than two independent means. Such analyses were carried out using the computer program SPSS-18 (Statistical Packages for Social Sciences-version 18).

\section{Results:}

In the basis of ELISA test anti- $T$. gondii antibodies ( $\operatorname{IgG}$ and $\operatorname{IgM}$ ), detected in the patients sera, three types of toxoplasmosis were identified. These were; acute type (negative for $\operatorname{IgG}$ and positive for $\operatorname{IgM}$ ), sub-acute type (positive for $\operatorname{IgG}$ and $\operatorname{IgM}$ ) and chronic type (positive for $\operatorname{IgG}$ and negative for $\operatorname{IgM})$. Most of patients had chronic type $75(86.2 \%)$ (Figure 1). Table 1 illustrates that all lipid profile of $T$. gondii infected women. There were significant decreased in the total cholesterol 165.05 (control groups 212.44, 213.33 respectively), triglycerides 134.98 (control groups 173.81, 174.40 respectively), LDL 87.78 (control groups 137.32, 135.87 respectively) and vLDL values 26.99 (control groups 34.70, 34.60 respectively). In contrast, there was significant increased in HDL value (49.0) as compared with control groups (40.42, 38.78 respectively).The results indicated that there were no significant differences in lipid profile values (total cholesterol, triglycerides, LDL, HDL and vLDL) between the three types of disease (Table 2).

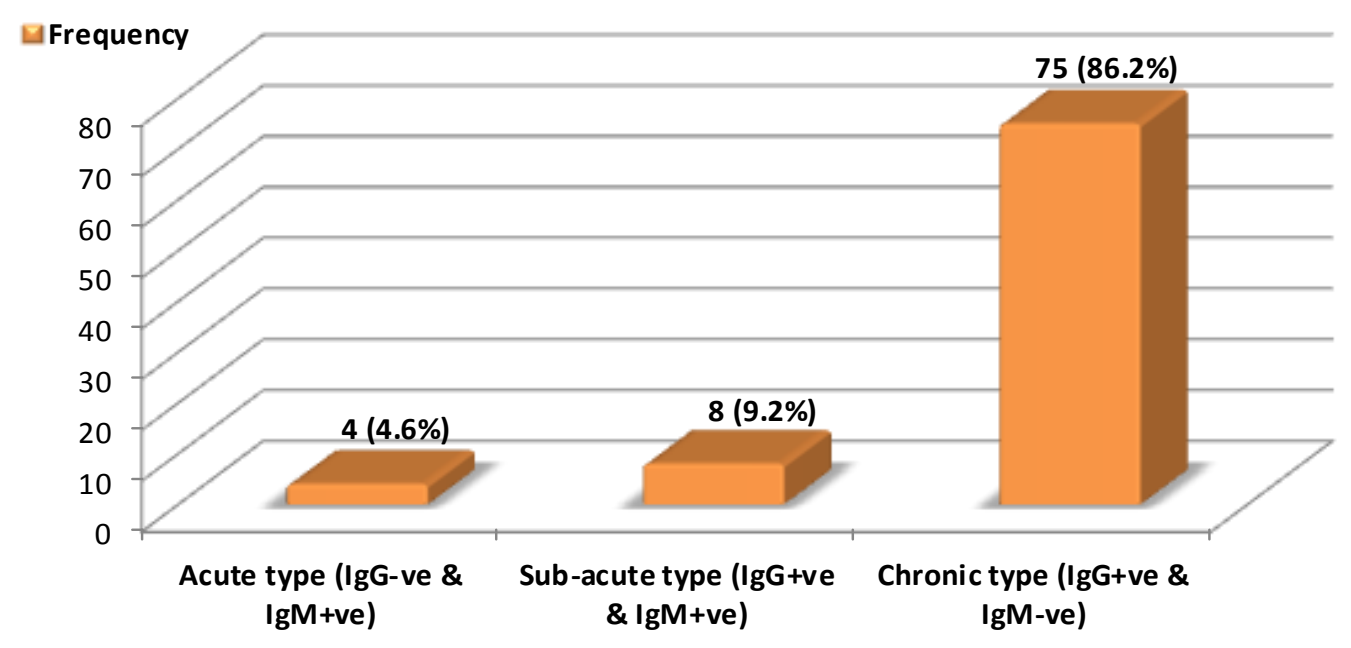

Fig. 1: Type of toxoplasmosis according to anti-Toxoplasma gondii antibodies (IgG and $\operatorname{IgM}$ ) detected by ELISA in the sera of patients. 
Table 1: Lipid profile values of women infected with Toxoplasma gondi and control groups.

\begin{tabular}{|c|c|c|c|c|}
\hline Lipid profile & $\begin{array}{c}\text { Patients } \\
\text { Mean } \pm \text { SEM } \\
\text { (Range) }\end{array}$ & $\begin{array}{c}\text { First control group } \\
\text { Mean } \pm \text { SEM } \\
\text { (Range) }\end{array}$ & $\begin{array}{c}\text { second control } \\
\text { group Mean } \pm \text { SEM } \\
(\text { Range })\end{array}$ & F; D.F; P-value \\
\hline $\begin{array}{l}\text { Total cholesterol } \\
(\mathrm{mg} / \mathrm{dL})\end{array}$ & $\begin{array}{c}165.05 \pm 4.81 \\
(100.0-391.0)\end{array}$ & $\begin{array}{c}212.44 \pm 4.82 \\
(150.0-380.0) \\
\end{array}$ & $\underset{(150.0-385.0)}{213.33_{ \pm 4.92}}$ & $32.41 ; 259,2 ; 0.0001 *$ \\
\hline $\begin{array}{l}\text { Triglycerides } \\
(\mathrm{mg} / \mathrm{dL})\end{array}$ & $\begin{array}{c}134.98 \pm 4.86 \\
(66.0-273.0)\end{array}$ & $\begin{array}{c}173.81 \pm 3.57 \\
(120.0-280.0)\end{array}$ & $\begin{array}{c}174.40_{ \pm 4.67} \\
(125.0-275.0)\end{array}$ & $26.34 ; 259,2 ; 0.0001 *$ \\
\hline HDL (mg/dL) & $\begin{array}{l}49.00_{ \pm} 1.32 \\
(22.0-67.0)\end{array}$ & $\begin{array}{l}40.42 \pm 0.58 \\
(30.0-50.0)\end{array}$ & $\begin{array}{c}38.78_{ \pm 0.91} \\
(32.0-41.0)\end{array}$ & $31.16 ; 259,2 ; 0.0001 *$ \\
\hline LDL (mg/dL) & $\begin{array}{c}87.78 \pm 4.97 \\
(15.0-300.0)\end{array}$ & $\begin{array}{l}137.32 \pm 4.67 \\
(76.0-298.0)\end{array}$ & $\begin{array}{c}135.87_{ \pm 3.85} \\
(77.0-287.0)\end{array}$ & $38.79 ; 259,2 ; 0.0001 *$ \\
\hline vLDL (mg/dL) & $\begin{array}{l}26.99_{ \pm} 1.01 \\
(13.0-54.0)\end{array}$ & $\begin{array}{l}34.70 \pm 0.71 \\
(24.0-56.0)\end{array}$ & $\begin{array}{l}34.60-0.71 \\
(26.0-54.0)\end{array}$ & $28.93 ; 259,2 ; 0.0001 *$ \\
\hline LDL/HDL ratio & $\begin{array}{c}2.08_{ \pm} 0.17 \\
(0.2-7.1)\end{array}$ & $\begin{array}{l}3.59_{ \pm} 0.18 \\
(1.5-9.3)\end{array}$ & $\begin{array}{c}3.38-0.17 \\
(1.6-8.9)\end{array}$ & $22.22 ; 259,2 ; 0.0001 *$ \\
\hline
\end{tabular}

$*$ P-value =highly significant.

Table 2: Lipid profile values (Mean \pm SEM \& Range) in the three types of toxoplasmosis in infected women.

\begin{tabular}{|l|l|l|l|l|}
\hline Lipid profile values & $\begin{array}{l}\text { Acute type } \\
\text { (IgG-ve \& } \\
\text { IgM+ve) }\end{array}$ & $\begin{array}{l}\text { Sub-acute type } \\
\text { IgG+ve \& } \\
\text { IgM+ve) }\end{array}$ & $\begin{array}{l}\text { Chronic type } \\
\text { (IgG+ve \& } \\
\text { IgM-ve) }\end{array}$ & D.F; P value \\
\hline Total cholesterol $(\mathbf{m g} / \mathbf{d L})$ & $202.25 \pm 37.69$ & $154.13_{ \pm} 10.40$ & $164.23_{ \pm} 5.09$ & $1.647 ; 84,2 ; 0.199 *$ \\
\hline Triglycerides $(\mathbf{m g} / \mathbf{d L})$ & $163.50_{ \pm} 36.24$ & $145.75_{ \pm} 16.26$ & $132.31_{ \pm} 5.05$ & $1.150 ; 84,2 ; 0.322^{*}$ \\
\hline HDL $(\mathbf{m g} / \mathbf{d L})$ & $47.50_{ \pm} 6.51$ & $43.25_{ \pm} 4.76$ & $49.69_{ \pm} 1.41$ & $1.019 ; 84,2 ; 0.365^{*}$ \\
\hline LDL $(\mathbf{m g} / \mathbf{d L})$ & $120.00_{ \pm} 32.08$ & $81.75_{ \pm} 12.96$ & $86.71_{ \pm} 5.35$ & $1.055 ; 84,2 ; 0.353^{*}$ \\
\hline vLDL (mg/dL) & $32.50_{ \pm} 7.33$ & $29.13_{ \pm} 3.30$ & $26.47_{ \pm} 1.05$ & $1.013 ; 84,2 ; 0.367^{*}$ \\
\hline LDL/HDL ratio & $2.90_{ \pm} 1.14$ & $2.19_{ \pm 0} .53$ & $2.02_{ \pm 0} .19$ & $0.572 ; 84,2 ; 0.567^{*}$ \\
\hline
\end{tabular}

$* \mathrm{P}-\mathrm{value}=$ not significant. 


\section{Discussion:}

This study revealed interesting results confirming that $T$. gondii reduces an atherogenic index in infected women. This confirmation approved by: the lipid profile picture, which revealed decrease in cholesterol and triglycerides and the lipid peroxidation status that characterized by significant increase in HDL level. The relationship of serum cholesterol levels in human infected with parasites has drawn the attention of various workers. Toxoplasma cannot synthesize cholesterol novo and depends upon acquisition of LDL-derived cholesterol from the host cell, via endocytosis mediated by the LDL receptor [18] or the LDL receptor-related protein [16]. A mechanism by which host and not parasite cholesterol controls the entry of Toxoplasma into cells has been proposed [19]. These studies indicated that cholesterol does have an important role in pathogenesis of toxoplasmosis. However, data on parasite lipid sources are scarce and the molecular mechanisms by which Toxoplasma acquires host cell lipids are largely unknown [20]. The previous studies have shown elevated levels of lipoproteins like HDL, LDL and total cholesterol in patients suffering from parasitic infection [21]. The changes in plasma lipoprotein were seen in many diseases such as in among those infected with HIV and taking antiviral therapy, total cholesterol, and in some cases, HDL was increased [22], and the same results were obtained in this study especially with HDL. Opposite results were obtained by other workers, this may be due to the chronic nature of the disease since the majority of cases in this study are chronic type (Figure 1). Since, in acute malaria infection resulting in decreased levels of HDL and LDL and moderately increased triglycerides [23]. In another study HDL is altered "acute phase HDL", including a reduction of HDL, decreased antioxidant activity, and other structural-compositional changes and interactions with inflammatory proteins [24]. Another study indicated that the reason for decreased HDL may be the acute phase response, which is an immediate reaction, associated with hypertriglyceridemia. Future studies may be needed to characterize the HDL particle, during acute and chronic phase's responses of toxoplasmosis. Finally, this study observed no significant differences in the lipid profile levels between the three types of toxoplasmosis. This may be due to the low number of cases in acute and sub acute disease in this study, but this what we could collect in the period of the research. In conclusion, this study showed that $T$. gondii had a role in changes lipid profile values in infected women which characterized by decrease in cholesterol and triglyceride and LDL with a significant increases in HDL level. Further studies are needed to maintain the effect of duration of the toxoplasmosis on the changes in lipid profile.

\section{References:}

1. Bonfioli A. A. and Orefice F. 2005. Toxoplasmosis. Seminar in Ophthalmology, 20:129-41.

2. Dunn D., Wallon M. and Peyron F. 1999. Mother to child transmission of Toxoplasmosis: Risk estimates for clinical counseling. Lancet, 353: 1829-33.

3. Remington J. S. 2001. Toxoplasmosis. In: Remington, J. S. and Klein, J. O. (eds). $5^{\text {th }}$ ed. W. B. Saunders Company, Philadelphia, pp. 205-346.

4. Abdel-Hafez S. K., Shbeeb I., Ismail N. S. and Abdel-Rahman F. 1986. Serodiagnosis of T. gondii in habitually aborting women and 
other adults from North Jordan. Folia. Parasitol., 33:7-13.

5. Mohammed H. N., Bener A. and Al-Kasme T. 1998. Toxoplasma antibody prevalence among healthy in United Arab Emirate. Saudi. Med. J., 19: 289-93.

6. Soliman M., Our-Eldin M. S. and Inaggar H. M. 2001. Toxoplasma antibody in normal and complicated pregnancy. J. Egy. Soci. Parasitol., 31: 37-46.

7. AL-Fertosi R. B. 2006. Immunopathology behind Toxoplasma gondii induced abortion: the role of IFN-y, IFN-y R-L (CD119) and IFN-y r1/IFN-y ratio in the induction of abortion. M.Sc. Thesis. College of Medicine, University of AL-Nahrain.

8. Kalil H. E. 2008. Some aspects in serprevalence, diagnosis and influence of sex hormones on immunity during human toxoplasmosis. Ph. D. Thesis. College of Medicine, University of Al-Mustansiriyah.

9. Jahangiri A., de Beer M. C., Noffsinger V., Tannock L. R., Ramaiah C., Webb N. R., van der Westhuyzen D. and de Beer F. C. 2009. HDL remodeling during the acute phase response. Arterioscler Throm. Vasc. Biol., 29:261-267.

10. McGullicuddy F. C., de la Llera Moy M., Hinkle C. C., Joshi M. R., Chinquoine E. H., Billheimer J. T., Rothblat G. H. and Reilly M. P. 2009. Inflammation impairs reverse cholesterol transport in vivo. Circulation 119:1135-1145.

11. Devendra B., Harinderpal S. B. and Rakesh S. 2005. Review: Role of cholesterol in parasitic infections. http://www.lipidworld.com/content/ $4 / 1 / 10$

12. Maxfield F. R. 2002. Plasma membrane microdomains. Curr. Opin. Cell Biol., 14: 483-87.
13. Faucher J. F., Milama E. N., Missinou M. A., Ngomo R., Kombila M. and Kremsner P. G. 2002. The impact of malaria on common lipid parameters. Parasitol. Res., 88:1040-43.

14. Al-Kennany E. R. 2007. Pathological study on the capability of Toxoplasma gondii to induce oxidative stress and initiation a primary lesion of atherosclerosis experimentally in broiler chickens. J. Anim. Veter. Adv., 6: 938-42.

15. Coppens I., Sinai A. P. and Joiner K. A. 2000. Toxoplasma gondii exploits host low-density lipoprotein receptor-mediated endocytosis for cholesterol acquisition. J. Cell Biol., 149: 167180.

16. Portugal L. R., Fernandes L. R., Pietra Pedroso V. S., Santiago H. C., Gazzinelli R. T. and AlvarezLeite J. I. 2008. Influence of lowdensity lipoprotein (LDL) receptor on lipid composition, inflammation and parasitism during Toxoplasma gondii infection. Microbes Infect., 10: 276-284.

17. Friedewald W. T., Levy, R. I. and Fredrickson D. S. 1972. Estimation of the concentration of low-density lipoprotein cholesterol in plasma without use of the preparative ultracentrifuge. Clin. Chemi., 18: 499-502.

18. Coppens I., Sinai A. P. and Joiner K. A. 2000. Toxoplasma gondii exploits host low-density lipoprotein receptor-mediated endocytosis for cholesterol acquisition. J. Cell Biol., 149: 167180.

19. Coppens I. and Joiner K. A. 2003. Host, but not parasite cholesterol controls Toxoplasma cell entry by modulating organelle discharge. Mol. Biol. Cell, 14: 3804-3820.

20. Coppens I. 2006. Contribution of host lipids to Toxoplasma 
pathogenesis. Cell Microbiol., 8: 19.

21. Djoumessi S. 1989. Serum lipids and lipoproteins during malaria infection. Pathol. Biol., 37: 909-11.

22. Rimland D., Guest J. L., Herna'ndez-Ramos I., Del Rio C., Le N. A. and Brown W. V. 2006. Antiretroviral therapy in HIVpositive women is associated with increased apolipoproteins and total cholesterol. J Acquir. Immune. Defic. Syndr., 42:307-313.
23. Nilson E.I. and Nilson E. P. 1990. Changes in plasma lipoproteins in acute malaria. J. Intern. Med., 227: 151-55.

24. Khovidhunkit W., Kim M.S., Mmon R. A., Shigenaga J. K., Moser A. H., Feingold K. R. and Grunfeld C. 2004. Effects of infection and inflammation on lipid and lipoprotein metabolism: mechanisms and consequences to the host. J. Lipid Res., 45:11691196.

\section{التغييرات في مستوى الدهون في النِساءَ المجهضات والمصابات بداء المقوسات}

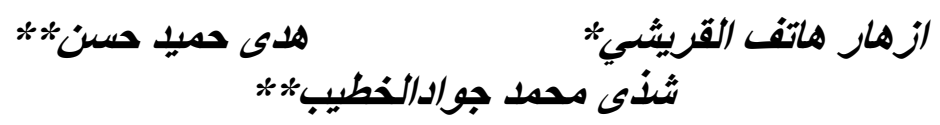

"فرع الاحياء المجهرية، كلية الطب، الجامعة المستتصرية.

" ترع الكيمياء الحياتية، كلية الطب، الجامعة المستتصرية.

\section{الخلاصة :}

تلعب دهون الدم دورالوسيط المهم في دفاع المضيف أثثاء المرحلة الحادة من المناعة الذاتية. تحفزالطفيليات على

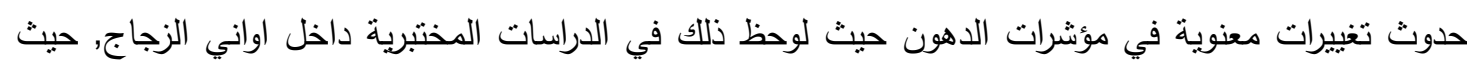

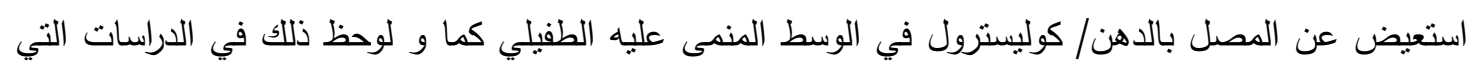
اجريت داخل نموذج مختبري (داخل الكائن الحي). ان طفيلي المقوسات الكوندية قادر تصنيع مادة الكوليسترول الخاص به لذلك تعتمد على إستهلاك بروتين الكثافة الثحمي المنخفض (LDL)

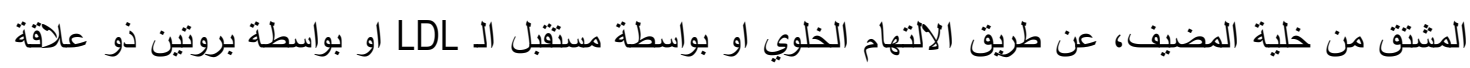
بمستقبل الـ LDL. تهدف الدراسة الحالية لتقييم التغييرات في مستوى الدهون في النساء المصابات بطفيلي المقوسات الكوندية Tondii. تضمنت عينة المرضى 87 إمرأة مجهضة لديهن نتيجة موجبة لفحص اضداد داء المقوسات و مجموعتي سيطرة (115 إمرأة) جمعت من مستشفى اليرموك التعليمي في بغداد. مجموعة السبطرة

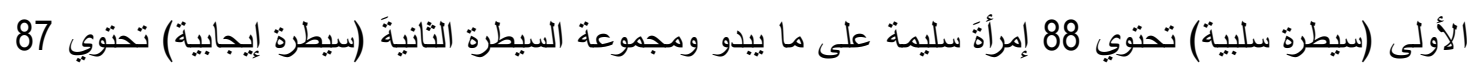

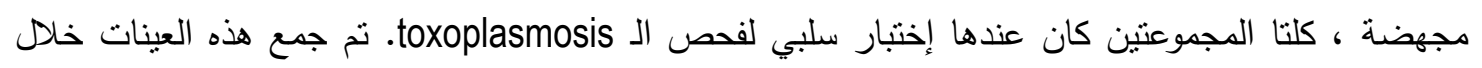

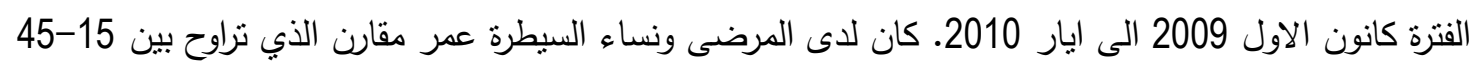

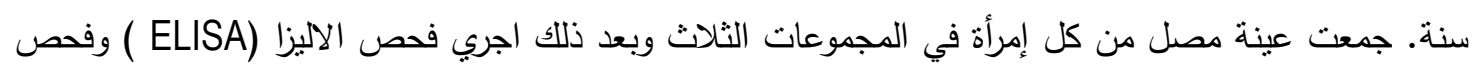

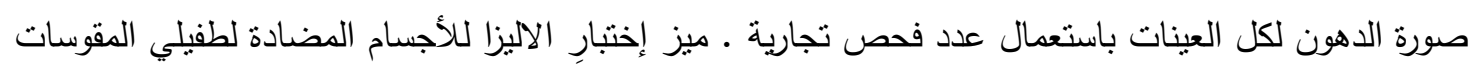

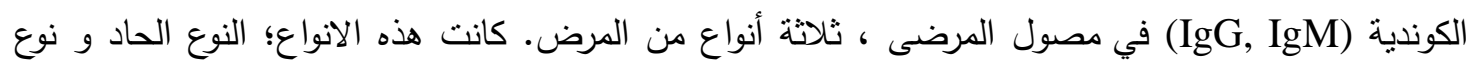


تحت الحاد ونوع مزمن. أغلب المرضى كان عندهم نوع المزمن 75 (86.2 \% \%). كان هناك نقص معنوي في

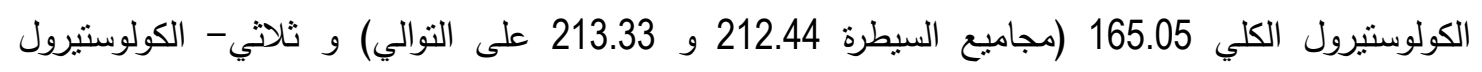

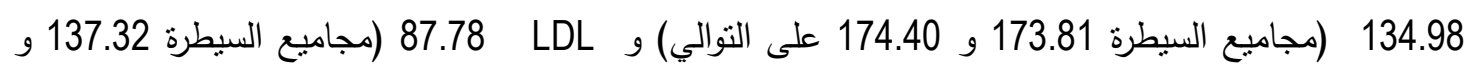

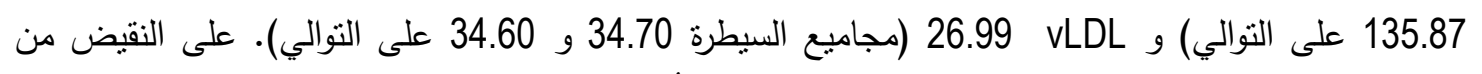

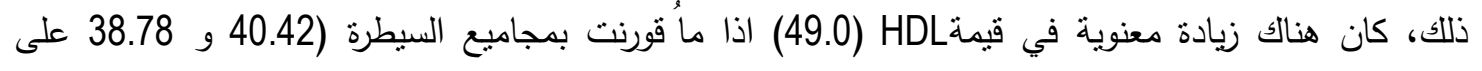

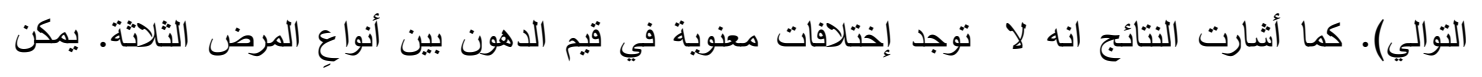

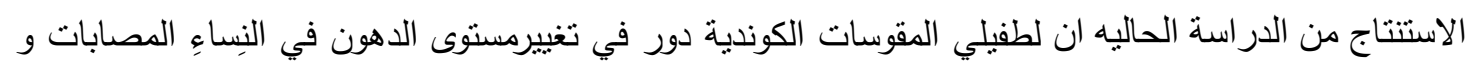

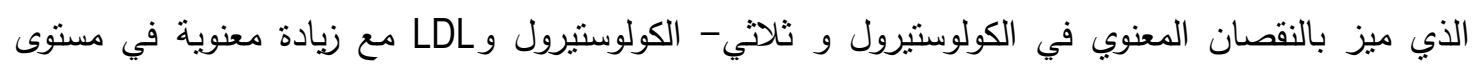

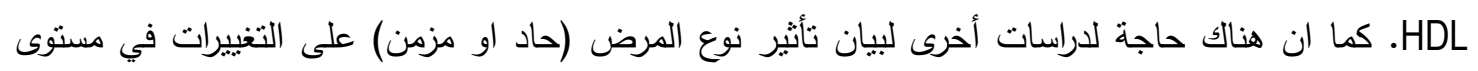
الدهون. 